\title{
Crystal Structure of $\mathrm{Y}_{2} \mathrm{Cu}_{2} \mathrm{O}_{5}$ Refined from Powder Neutron Diffraction Data
}

\author{
H. Fjellvåg, P. Karen and A. Kjekshus \\ Department of Chemistry, University of Oslo, Blindern, N-0315 Oslo 3, Norway
}

\begin{abstract}
Fjellvåg, H., Karen, P. and Kjekshus, A., 1988. Crystal Structure of $\mathrm{Y}_{2} \mathrm{Cu}_{2} \mathrm{O}_{5}$ Refined from Powder Neutron Diffraction Data. - Acta Chem. Scand., Ser. A 42: $144-147$.
\end{abstract}

\begin{abstract}
A booming need for reliable information on the structural, thermodynamic and other physical properties of all binary, ternary and quaternary phases in the $\mathrm{Y}-\mathrm{Ba}-\mathrm{Cu}-\mathrm{O}$ system has been placed in the focus of scientific interest after the recent discovery of high-temperature superconductivity for $\mathrm{YBa}_{2} \mathrm{Cu}_{3} \mathrm{O}_{9-\delta}(\delta \approx 2) .^{1-3}$ The turquoise-blue, normal valence, semiconducting compound $\mathrm{Y}_{2} \mathrm{Cu}_{2} \mathrm{O}_{5}{ }^{4-7}$ is a ternary phase of this system reported to be isostructural with $\mathrm{Ho}_{2} \mathrm{Cu}_{2} \mathrm{O}_{5} ;{ }^{8}$ however, a detailed structure characterization is lacking. The present communication reports on the crystal structure of $\mathrm{Y}_{2} \mathrm{Cu}_{2} \mathrm{O}_{5}$ between 20 and $1300 \mathrm{~K}$ as determined by powder $\mathrm{X}$-ray and neutron diffraction.
\end{abstract}

\section{Experimental}

Powder specimens of $\mathrm{Y}_{2} \mathrm{Cu}_{2} \mathrm{O}_{5}$ were prepared from $\mathrm{Y}_{2} \mathrm{O}_{3}$ (Megon, 99.999\%) and $\mathrm{CuO}$ (Merck, reagent grade) as described in Ref. 9. Powder $\mathrm{X}$-ray diffraction data were collected at $295 \mathrm{~K}$ with Guinier cameras $\left(\mathrm{CuK \alpha _{1 }}\right.$ and $\mathrm{Cr} K \alpha_{1}$ radiation, $\mathrm{Si}$ as internal standard $\left.{ }^{10}\right)$. Similar hightemperature data were obtained between 300 and $1300 \mathrm{~K}$ with a Guinier Simon camera. Unit cell dimensions were calculated by least-squares refinements. ${ }^{11}$ Powder neutron diffraction data were collected between 20 and $295 \mathrm{~K}$ with the OPUS III two-axis diffractometer at the JEEP II reactor, Kjeller, Norway, using monochromatic neutrons of wavelength $187.7 \mathrm{pm}$. Diffraction data were collected in steps of $\Delta(2 \theta)=0.05^{\circ}$ between $2 \theta=5$ and $100^{\circ}$. Profile refinement was carried out according to the Rietveld method, ${ }^{12}$ using the Hewat ${ }^{13}$ version of the programme. The scattering lengths, $b_{\mathrm{Y}}=7.75, b_{\mathrm{Cu}}=7.718$ and $b_{\mathrm{O}}$ $=5.805 \mathrm{fm}$, were taken from Ref. 14. In the profile refinements, constraints in the form of common isotropic temperature factors for nonequivalent yttrium, copper and oxygen atoms were introduced (the present powder data and the large number of structural variables do not justify introduction of anisotropic thermal parameters as additional variables).

\section{Results and discussion}

The powder $\mathrm{X}$-ray and neutron diffraction patterns clearly show that $\mathrm{Y}_{2} \mathrm{Cu}_{2} \mathrm{O}_{5}$ is isostructural with $\mathrm{Ho}_{2} \mathrm{Cu}_{2} \mathrm{O}_{5} \cdot{ }^{8}$ The deduced unit cell dimensions (at $295 \mathrm{~K}$ ) $a=1080.03 \pm 0.08, b=349.53$ \pm 0.02 and $c=1245.88 \pm 0.08 \mathrm{pm}$ (space group $P n a 2_{1}$ ) fit excellently the results in Refs. 6 and 7. The virtually identical powder neutron diffraction patterns at $20,100,200$ and $295 \mathrm{~K}$, as well as the results of the profile refinements, imply that no structural or magnetic phase transition occurs in the temperature interval 20 to $295 \mathrm{~K}$. The observed neutron diffraction pattern for $\mathrm{Y}_{2} \mathrm{Cu}_{2} \mathrm{O}_{5}$ at $20 \mathrm{~K}$ is shown in Fig. 1 together with the corresponding difference diagram after Rietveld (profile) refinement, unconstrained positional parameters being listed in Table 1.

The crystal structure of $\mathrm{Y}_{2} \mathrm{Cu}_{2} \mathrm{O}_{5}$ is of the $\mathrm{Ho}_{2} \mathrm{Cu}_{2} \mathrm{O}_{5}$ type, ${ }^{8}$ which is adopted for $\mathrm{M}_{2} \mathrm{Cu}_{2} \mathrm{O}_{5}$ with various trivalent elements $\mathrm{M}$, e.g. $\mathrm{M}=\mathrm{In},{ }^{15}$ 


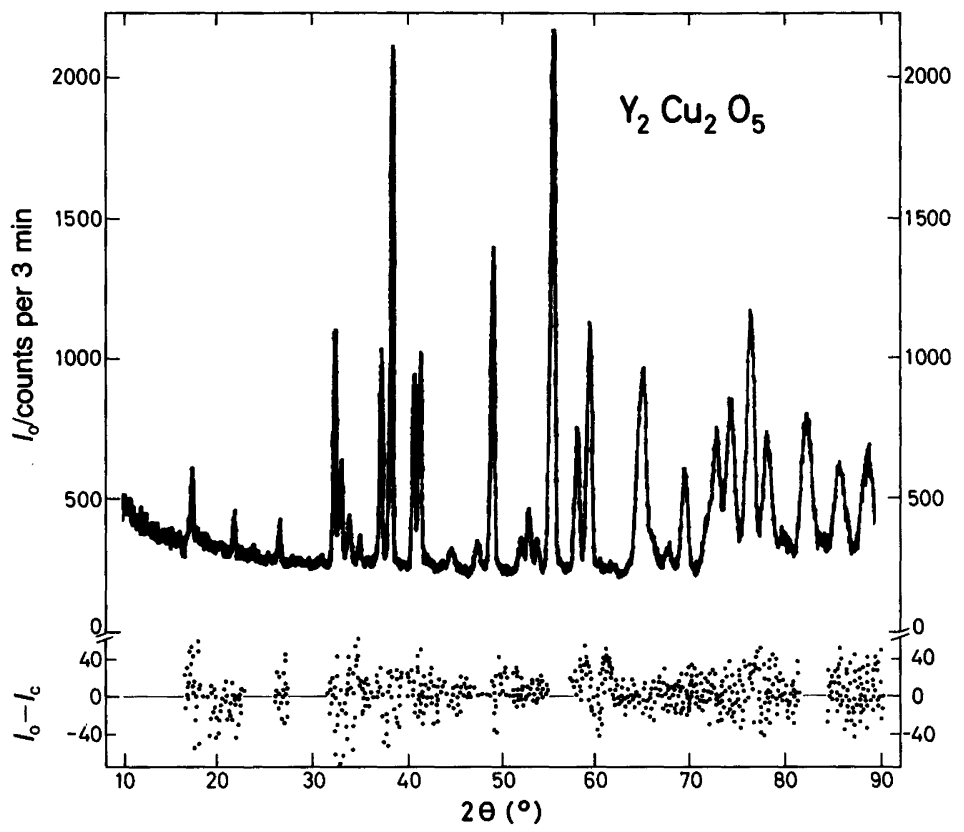

Fig. 1. The observed powder neutron diffraction pattern $\left(I_{0}\right)$ for $\mathrm{Y}_{2} \mathrm{Cu}_{2} \mathrm{O}_{5}$ at $20 \mathrm{~K}$, together with the corresponding difference diagram $\left(I_{0}-I_{c}\right)$ after Rietveld refinement.

$\mathrm{Sc},{ }^{16} \mathrm{Y}^{4,6,7} \mathrm{Ho}^{8}$ and $\mathrm{Lu}^{16}$ The $\mathrm{M}$ atom is coordinated by a distorted octahedron of oxygen atoms. The copper atoms have four neighbouring oxygen atoms, and the coordination may very roughly be described as square planar; one atom

Table 1. Positional parameters for $\mathrm{Y}_{2} \mathrm{Cu}_{2} \mathrm{O}_{5}$ at $20 \mathrm{~K}$ as obtained by Rietveld analysis of powder neutron diffraction data. Space group Pna2 ${ }_{1}$, all atoms in $4 a$ positions, $R_{\mathrm{n}}=0.040$. Calculated standard deviations in parentheses. Unit cell dimensions (pm): $a=$ $1079.6 \pm 0.2, b=349.4 \pm 0.1$ and $c=1245.7 \pm$ 0.2 . Isotropic temperature factors $\left(10^{-4} \mathrm{pm}^{2}\right): 0.2 \pm$ $0.1,0.5 \pm 0.1$ and $0.1 \pm 0.1$ for $\mathrm{Y}, \mathrm{Cu}$ and $\mathrm{O}$, respectively.

\begin{tabular}{llll}
\hline Atom & $x$ & $y$ & $z$ \\
\hline$Y_{\text {I }}$ & $0.204(1)$ & $0.218(3)$ & 0 \\
$Y_{\text {II }}$ & $0.038(1)$ & $0.222(3)$ & $0.3304(5)$ \\
$\mathrm{Cu}_{1}$ & $0.986(1)$ & $0.662(3)$ & $0.115(2)$ \\
$\mathrm{Cu}_{\text {II }}$ & $0.256(1)$ & $0.673(2)$ & $0.217(1)$ \\
$\mathrm{O}_{\text {I }}$ & $0.173(3)$ & $0.733(4)$ & $0.354(2)$ \\
$\mathrm{O}_{\text {II }}$ & $0.325(2)$ & $0.705(3)$ & $0.060(1)$ \\
$\mathrm{O}_{\text {III }}$ & $0.123(2)$ & $0.321(3)$ & $0.179(2)$ \\
$\mathrm{O}_{\text {IV }}$ & $0.431(2)$ & $0.775(4)$ & $0.255(1)$ \\
$\mathrm{O}_{\mathrm{V}}$ & $0.425(3)$ & $0.210(4)$ & $0.472(2)$ \\
\hline
\end{tabular}

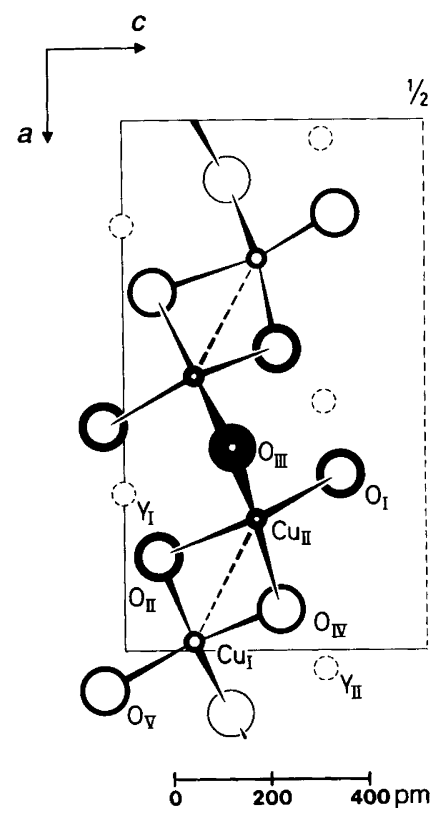

Fig. 2. A selected part of the $\mathrm{Y}_{2} \mathrm{Cu}_{2} \mathrm{O}_{5}$ structure shown in projection on the ac plane. The numbering of the atoms is shown in the illustration. 
Table 2. Interatomic distances (pm) up to $300 \mathrm{pm}$ in $\mathrm{Y}_{2} \mathrm{Cu}_{2} \mathrm{O}_{5}$ at $20 \mathrm{~K}$. Calculated standard deviations in parentheses.

\begin{tabular}{rrrr}
\hline$Y_{1}-O_{1}$ & $226(3)$ & $\mathrm{Cu}_{1}-\mathrm{O}_{\mathrm{II}}$ & $193(3)$ \\
$-\mathrm{O}_{\mathrm{II}}$ & $234(2)$ & $-\mathrm{O}_{\mathrm{III}}$ & $206(3)$ \\
$-\mathrm{O}_{\mathrm{II}}$ & $227(2)$ & $-\mathrm{O}_{\mathrm{II}}$ & $285(2)$ \\
$-\mathrm{O}_{\mathrm{III}}$ & $242(2)$ & $-\mathrm{O}_{\mathrm{IV}}$ & $186(3)$ \\
$-\mathrm{O}_{\mathrm{v}}$ & $228(3)$ & $-\mathrm{O}_{\mathrm{v}}$ & $203(4)$ \\
$-\mathrm{O}_{\mathrm{V}}$ & $224(3)$ & & \\
& & $\mathrm{Cu}_{1}-\mathrm{Cu}_{\mathrm{II}}$ & $285(3)$ \\
$\mathrm{Y}_{\mathrm{II}}-\mathrm{O}_{\mathrm{I}}$ & $226(3)$ & & \\
$-\mathrm{O}_{\mathrm{I}}$ & $232(3)$ & $\mathrm{Cu}_{\mathrm{II}}-\mathrm{O}_{\mathrm{I}}$ & $194(3)$ \\
$-\mathrm{O}_{\mathrm{III}}$ & $213(3)$ & $-\mathrm{O}_{\mathrm{II}}$ & $210(3)$ \\
$-\mathrm{O}_{\mathrm{IV}}$ & $229(2)$ & $-\mathrm{O}_{\mathrm{III}}$ & $195) 3)$ \\
$-\mathrm{O}_{\mathrm{IV}}$ & $231(2)$ & $-\mathrm{O}_{\mathrm{II}}$ & $273(2)$ \\
$-\mathrm{O}_{\mathrm{v}}$ & $216(2)$ & $-\mathrm{O}_{\mathrm{IV}}$ & $198(3)$ \\
\hline
\end{tabular}

is, however, significantly shifted out of the plane (Fig. 2). The calculated interatomic distances are given in Table 2 . There is considerable variation in the $\mathrm{Y}-\mathrm{O}$ bond distances, with distinction being made between $Y_{I}$ and $Y_{I I}$, which have average $\mathrm{Y}-\mathrm{O}$ distances of 230 and $224 \mathrm{pm}$, respectively. If one uses bond strength considerations to evaluate the valence of yttrium, the valences of $Y_{I}$ and $Y_{I I}$ turn out to be quite different. According to the Zachariasen formula, ${ }^{17} 2.86$ and 3.44 valence units, respectively, are obtained. However, exactly the same - somewhat disturbing - structural feature is found for the isostructural In, ${ }^{15}$ $\mathrm{Ho}^{8}$ and $\mathrm{Lu}^{16}$ compounds.

Considerations of the same type (using parameters given by Brown and Shannon ${ }^{18}$ ) yield 1.84 and 1.74 valence units, respectively, for the crystallographically different $\mathrm{Cu}_{\mathrm{I}}$ and $\mathrm{Cu}_{\mathrm{II}}$ atoms. These are both significantly lower than the expected value of 2 . However, once again the same feature is common to the $\mathrm{Ho}_{2} \mathrm{Cu}_{2} \mathrm{O}_{5}$ type family. The apparently too low valence(s) for copper can probably be rationalized in terms of significant $\mathrm{Cu}-\mathrm{Cu}$ interaction. As seen from Fig. 2, $\mathrm{Cu}_{\mathrm{I}}$ and $\mathrm{Cu}_{\mathrm{II}}$ form pairs with an interatomic distance of $285 \pm 3 \mathrm{pm}$ in $\mathrm{Y}_{2} \mathrm{Cu}_{2} \mathrm{O}_{5}$. Within the estimated standard deviation, identical $\mathrm{Cu}_{\mathrm{I}}-\mathrm{Cu}_{\mathrm{II}}$ separations are found in $\mathrm{M}_{2} \mathrm{Cu}_{2} \mathrm{O}_{5}$ with $\mathrm{M}=\mathrm{In},{ }^{15} \mathrm{Sc},{ }^{16}$ $\mathrm{Ho}^{8}$ and $\mathrm{Lu} .{ }^{16}$

A closer look at the $\mathrm{Y}_{2} \mathrm{Cu}_{2} \mathrm{O}_{5}$ structure (Fig. 2) reveals that characteristic, almost planar $\mathrm{Cu}_{2} \mathrm{O}_{4}$ units are interconnected parallel to the $b$ axis by bridging $\mathrm{O}_{\mathrm{III}}$ atoms to form one-dimensional
$\mathrm{Cu}_{2} \mathrm{O}_{5}$ chains. The yttrium atoms occupy octahedral sites between these chains. The interatomic $\mathrm{Cu}_{1}-\mathrm{Cu}_{\mathrm{II}}$ distance within the $\mathrm{Cu}_{2} \mathrm{O}_{4}$ unit is short $(\sim 285 \mathrm{pm}$, vide supra $)$, whereas the $\mathrm{Cu}-\mathrm{Cu}$ separation between the units is appreciably greater $(\sim 316 \mathrm{~m})$. It is possible that competition between square-planar coordination of $\mathrm{Cu}$ and octahedral coordination of $\mathrm{Y}$ is the origin of the large scatter in interatomic distances as well as of the difference between the calculated bond strengths for the two types of yttrium atoms in the structure.

The variation in the unit cell dimensions for $\mathrm{Y}_{2} \mathrm{Cu}_{2} \mathrm{O}_{5}$ with temperature between 300 and 1300 $\mathrm{K}$ is shown in Fig. 3. No indication of any phase transition is found. The thermal expansion is rather small and the individual characteristics in Fig. 3 have a convex shape towards the temperature axis. If the expansion is approximated as

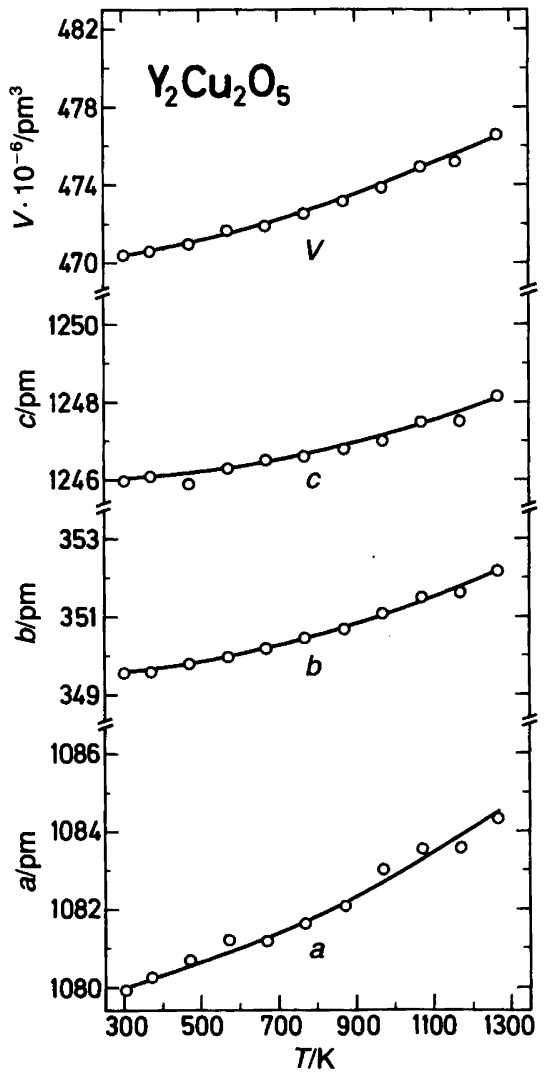

Fig. 3. Variation in unit cell dimensions of $\mathrm{Y}_{2} \mathrm{Cu}_{2} \mathrm{O}_{5}$ with temperature between 300 and $1300 \mathrm{~K}$. 
linear with temperature, the thermal expansion coefficients $\alpha_{a}=1 / a \cdot \Delta a / \Delta T=1.7 \cdot 10^{-6} \mathrm{~K}^{-1}, \alpha_{b}$ $=4.1 \cdot 10^{-6} \mathrm{~K}^{-1}, \alpha_{c}=7.6 \cdot 10^{-6} \mathrm{~K}^{-1}$ and $\alpha_{V}=$ $1.4 \cdot 10^{-5} \mathrm{~K}^{-1}$ are obtained.

Acknowledgement. This work has received financial support from the Royal Norwegian Council for Scientific and Industrial Research.

\section{References}

1. Cava, R. J., Batlogg, B., van Dover, R. B., Murphy, D. W., Sunshine, S., Siegrist, T., Remeika, J.P., Rietman, E. A., Zahurak, S. and Espinosa, G. P. Phys. Rev. Lett. 58 (1987) 1676.

2. Rao, C. N. R., Ganguly, P., Raychaudhuri, A. K., Mohan Ram, R. A. and Sreedhar, K. Nature (London) 326 (1987) 856.

3. Capponi, J. J., Chaillout, C., Hewat, A., Lejoy, P., Marezib, M., Ngyen, N., Raveau, B., Soubeyroux, J. L., Tholence, J. L. and Tournier, R. Europhys. Lett. 3 (1987) 1301.

4. Schmitz-DuMont, O. and Kasper, H. Monatsh. Chem. 96 (1965) 506.

5. Arjomand, M. and Machin, D. J. J. Chem. Soc., Dalton Trans. (1975) 1061.

6. Kimizuka, N., Takayama, E., Horiuchi, S., Yamamoto, A. and Fujita, T. J. Solid State Chem. 42 (1982) 322.
7. Lambert, U. and Eysel, W. Powder Diffraction 1 (1986) 45.

8. Freund, H. R. and Müller-Buschbaum, H. Z. Naturforsch., B 32 (1977) 609.

9. Fjellvåg, H., Karen, P. and Kjekshus, A. Acta Chem. Scand., Ser. A 41 (1987) 283.

10. Deslatters, R. D. and Henins, A. Phys. Rev. Lett. 31 (1973) 972.

11. Ersson, N. O. Program CELLKANT, Chemical Institute, Uppsala University, Uppsala, Sweden 1981.

12. Rietveld, H. M. J. Appl. Crystallogr. 1 (1968) 65.

13. Hewat, A. W. The Rietveld Computer Program for the Profile Refinement of Neutron Diffraction Powder Patterns Modified for Anisotropic Thermal Vibrations, UKAERE Harwell Rep. RRL 73/897, Harwell 1973.

14. Koester, L. and Yelon, W. B. In: Yelon, W. B., Ed., Neutron Diffraction Newsletter, The Neutron Diffraction Commission, Missouri 1983.

15. Freund, H. R. and Müller-Buschbaum, H. $Z$. Anorg. Allg. Chem. 441 (1978) 103.

16. Freund, H. R. and Müller-Buschbaum, H. Z. Naturforsch., B 38 (1977) 1123.

17. Zachariasen, W.H. J. Less-Common Met. 62 (1978) 1.

18. Brown, I. D. and Shannon, R.D. Acta Crystallogr., Sect. A 29 (1973) 266.

Received November 23, 1987. 